\title{
BAGAIMANA NUMBERED HEADS TOGETHER DAPAT MEMOTIVASI DAN MEMENUHI KEMAMPUAN MINIMUM LITERASI MEMBACA
}

\section{HOW TOGETHER'S NUMBERED HEADS CAN MOTIVATE AND MEET THE MINIMUM LITERACY READING ABILITY}

\author{
Putri Handayani \\ Pendidikan Dasar Universitas Negeri Semarang \\ puutriibaandaayaanii5@students.unnes.ac.id
}

DOI: 10.35438/cendekiawan.v3i2.223

Historical Articles

Submitted: 2021-07-03

Revised: 2021-12-14

Issued: 2021-12-30

Keywords: Reading

Literacy, Numbered Heads

Together Model

Kata kunci: Literasi

Membaca, Model

Numbered Heads Together
Reading literacy skills in Indonesia turned out to show data not much different from PIS A. Reading literacy skills in Indonesia in general is ranked 60th-out of 61 countries survey participants in terms of reading literacy ability. The results of the Indonesia National Assessment Program in 2016 conducted by the Center for Education Research ministry of education and culture itself revealed the results of the data showed that the national average distribution of literacy on reading literacy ability of a student in Indonesia is $46.83 \%$, only $6.06 \%$ is in the good category, and 47.11 is in the category of sufficient. This triggers researchers and educational practitioners to explore learning methods that can improve the minimum ability of reading literacy. This study will focus on how methods can improve students' motivation and reading literacy skills. This study was conducted with an in-depth review of nht-related literature published nationally and internationally. The main finding of this study is that numbered heads together can be motivating because it can improve the cooperation of learners and can also provide opportunities to share ideas and consider the right answers.

\section{Abstrak}

Data menunjukkan bahwa kemampuan literasi membaca Indonesia tidak jauh berbeda dengan PISA. Secara keseluruhan, di antara 61 negara peserta survei, literasi membaca Indonesia menempati urutan ke-60 dalam hal literasi membaca. Menurut hasil Program Evaluasi Nasional Indonesia 2016 yang dilakukan oleh Pusat Penelitian Pendidikan Kementerian Pendidikan dan Kebudayaan, data menunjukkan bahwa rata-rata nasional sebaran literasi membaca siswa Indonesia adalah 46,83\%. Hanya 6 0,06\% termasuk kategori baik dan 47,11 termasuk kategori cukup. Hal ini mendorong peneliti dan pendidik untuk menggali metode pembelajaran yang dapat meningkatkan kemampuan literasi membaca minimal. Penelitian ini akan fokus pada bagaimana metode numbering dapat meningkatkan motivasi dan kemampuan membaca peserta didik. Penelitian ini dilakukan melalui penelitian mendalam terhadap literatur-literatur terkait dengan numbered heads together yang diterbitkan baik di dalam negeri maupun di luar negeri. Temuan utama dari penelitian ini adalah berkumpulnya sejumlah orang secara bersamasama dapat merangsang semangat peserta didik, karena dapat meningkatkan kerjasama dan memberikan kesempatan untuk berbagi ide dan mempertimbangkan jawaban yang benar. 


\section{PENDAHULUAN}

Gerakan literasi sekolah ialah gerakan bertujuan menjadikan sekolah sebagai tempat belajar membaca, dengan melibatkan masyarakat, wadah dapat selalu literasi sepanjang hayatnya (Rofiah, 2019). (Ruhaena, 2015) mengungkapkan bahwa literasi membaca dilihat dari empat aspek. Pertama, mereka memastikan bahwa informasi itu benar. Kedua, ingatkan seseorang tentang sebuah pesan. Ketiga, menjelaskan sesuatu. Keempat, mencerminkan bentuk gagasan dalam bahasa lain. Permendikbud Nomor 23 Tahun 2015 menyebutkan bahwa sekolah perlu menyisihkan waktu secara rutin untuk membiasakan kegiatan literasi membaca, karena dapat mengembangkan karakter seseorang. Hal ini di kalangan masyarakat umum masih minim dengan kegiatan literasi membaca.

Literasi membaca sangatlah penting bagi masyarakat, terutama pada era informasi dan komunikasi sekarang ini. Dengan hal ini, para ahli sepakat bahwa kegiatan literasi membaca adalah sebagai syarat awal mutlak bagi setiap orang yang ingin berkembang dalam hidupnya (Ilmasari \& Alhadi, 2019).

Membaca adalah sebuah jembatan untuk masyarakat dan dimana saja yang berkeinginan meraih kesuksesan serta kemajuan dalam hidupnya terutama pada dunia persekolahan (Muntari, 2016). Kasus-kasus gagalnya pendidikan berdasarkan hasil survei di sebuah kota Sulawesi Selatan karena literasi rendah adanya beberapa faktor. Permasalahan pertama yaitu salah persepsi pada konsep kemampuan membaca termasuk pada pendidik dan peserta didik. Hal ini sering terjadi pada peserta didik sekolah dasar sehingga pembelajaran membaca akan berpengaruh pada kelas tinggi, karena pondasi awal membaca yang seharusnya berada pada kelas rendah dan permasalahan itu menjadi terabaikan sehingga akan mengakibatkan peserta didik dalam membaca. Faktor yang melatarbelakangi permasalahan tersebut adalah anggapan orangtua yang salah terhadap pendidik di sekolah karena mampu membelajarkan anaknya yang seharusnya membaca permulaan biasanya dilaksanakan pada kelas rendah yaitu I, dan II, III. Pada kelas tinggi, yakni kelas IV sampai kelas VI peserta didik belum mampu membaca pemahaman sehingga pengajaran masih menekankan pada pembelajaran seperti membaca nyaring, dan melancarkan bacaan setiap peserta didik masih dilakukan yang seharusnya diterapkan dan pelaksanaan pada kelas rendah.

Kasus pertanyaan kedua di Purbalingga, Jawa Tengah, adalah bahwa membaca berlaku untuk menggugurkan tugas dari tanggung jawab materi bahasa Indonesia. Hal ini sering terjadi, padahal kurikulum menekankan kepada pendidik bahwa mengembangkan kemampuan membaca tidak hanya pada materi pelajaran bahasa saja, melainkan bisa dengan mata pelajaran matematika, IPS, dan IPA. Seperti membaca pemahaman membaca grafik, pada peta, dan mengembangkan kemampuan membaca prosedur.

Kasus ketiga di Cilacap mengenai pembelajaran belum menggunakan metode, model, strategi, dan media pembelajaran pada kegiatan membaca pemahaman. Kasus ini masih banyak pendidik yang telah diobservasi pembelajaran masih monoton, membuat lembar kerja yang tidak menarik, sehingga peserta didik cenderung bosan dalam proses pembelajaran.

Kasus keempat, di Sidoarjo, Jawa Tengah, materi bacaan, kegiatan pembelajaran, dan soal latihan/penilaian dalam buku teks seringkali masih dianggap rendah. (berpikir tingkat rendah). Kurikulum 2013 (kurtilas) mengedepankan pada kompetensi untuk berpikir tingkat tinggi, yaitu pembelajaran HOTS (keterampilan berpikir tingkat tinggi) dan pendidik dapat menyusun rencana pembelajaran (RPP). (Leu, 2020) yaitu kualitasnya terhadap bahan bacaan setiap peserta didik. Harsiati menjelaskan bahwa literasi membaca PISA ditandai dengan fokusnya pada kemampuan berpikir tingkat tinggi, seperti mencari informasi, mengembangkan interpretasi dan 
refleksi. (Busroli, 2019) penyebab utama rendahnya angka melek huruf adalah kurangnya sarana dan prasarana, seperti perpustakaan sebagai pusat pengembangan keterampilan membaca.

Selain itu bisa dari seorang pendidik dan peserta didik (dalam diri dan dari luar siswa) yang kurang termotivasi dalam kegiatan literasi membaca. Oleh karena itu, banyak peneliti mengkaji mengenai literasi membaca karena literasi membaca sangat minim dan rendah terutama pada sekolah. (Arifian, 2018) menyarankan dua metode yaitu pertama, mengetahui alasan mengapa peserta didik tidak sabar dan berhati-hati saat bertemu dengan teks bacaan yang banyak dalam materi yang disediakan. Kedua, kita harus merumuskan kembali bagaimana membangun belajar membaca, bahan ajarnya, kualitas soal dan latihan evaluasinya, memberikan metode, model, strategi, dan media pembelajaran yang menarik sehingga para pelajar tidak terpaku dengan teks wacana bacaan dan terbiasa low order thinkings.

\section{METODE}

Peneliti melakukan penelaahan literatur dari berbagai sumber online dengan kata kunci : literasi membaca, model numbered heads together, motivasi dan kemampuan minimum (Suspahariati \& Susilawati, 2020). Literatur yang diperoleh dari sumber-sumber rujukan salah satunya buku cooperative learning dan data yang kedua adalah artikel prosiding, artikel yang terindeks sinta 1 sampai dengan 6 baik dari segi artikel nasional maupun artikel internasional kemudian proses tahapan peneliti yaitu mengidentifikasi data artikel, mereview artikel, mengevaluasi artikel, serta menjabarkan hasil pembahasan analisis data artikel.

\section{HASIL PENELITIAN}

\section{Literasi Membaca dan Upaya Peningkatannya}

Gerakan literasi membaca adalah salah satu aspek terampil dalam berbahasa (Handayani, 2020). Kegiatan literasi membaca merupakan kegiatan proses yang diterapkan pembaca untuk mendapatkan informasi yang ingin disampaikan kepada pengarang melalui bahasa tulis maupun teks. Ada beberapa jenis kegiatan literasi dasar, di antaranya peneliti fokus pada kegiatan literasi membaca dasar. Membaca keaksaraan dasar adalah jenis membaca keaksaraan dasar, yang melibatkan pengucapan tulisan dan pemikiran dalam memahami isi teks bacaan.

(Rahim, 2008) menjelaskan membaca meliputi kegiatan beberapa yaitu mengenalkan kata, memahami literal, interpretasi, membaca kritis, serta kreatif dalam proses berpikir. Sejalan dengan penjelasan tersebut, Finocchiaro mengatakan bahwa membaca adalah upaya cara seleksi dan bagaimana memahami isi yang terkandung pada bahasa tulis, termasuk makna yang tersirat dalam pengolahan informasi, silabus, sintaksis, dan semantik. (Rifqi, 2016) berdasarkan sudut pandang, dapat disimpulkan apabila literasi membaca dasar adalah aktivitas proses yang dilaksanakan oleh pembaca, yang tujuannya adalah untuk mengetahui arti dan mengkonstruksi isi dari beberapa informasi yang disampaikan melalui bentuk tulisan maupun secara tekstual.

Dengan literasi membaca, kita bisa memperoleh wawasan dari berbagai informasi, Mampu memahami makna dari hal-hal yang sedang dihadapi atau diteliti. Selain itu, literasi membaca penting karena bisa meningkatkan daya nalar peserta didik dan kemampuan keterampilan berbahasa. Hal ini senada dengan yang dikatakan (Zonalisa Fhatri, 2019) bahwa membaca literasi dasar bukan hanya kegiatan yang dilakukan dengan mengatakan apa yang kita lihat, tetapi pemahaman membaca dalam literasi adalah memahami pola bahasa dari deskripsi tertulis.

Gambaran umum kemampuan literasi dasar membaca siswa sekarang ini sangat rendah, masalah mendasar rendahnya motivasi dan kemampuan membaca pemahaman peserta didik berhubungan dengan ketersedian buku, perpustakaan kurang memadai, faktor situasional, dan 
pola asuh kedua orangtua. Tidak semua peserta didik mendapatkan buku yang berkualitas dan sesuai dengan usianya. Selain itu faktor ekonomi yang sangat rendah, kesedian orangtua untuk menyediakan buku di rumah menyebabkan peserta didik tidak mendapatkan buku apa yang mereka butuhkan. Selain itu, masih banyak yang menyebabkan bahwa kemampuan literasi membaca peserta didik rendah diakibatkan dengan sistem pembelajaran yang berjalan selama ini belum bisa memicu peserta didik dalam memiliki motivasi dalam literasi membaca dikarenakan pembelajaran masih berpusat dengan pendidik.

Penyebab rendahnya literasi membaca di Indonesia menurut Najela Shihab dengan upaya peningkatannya adalah literasi bukan kemampuan membaca, melainkan kemampuan bernalar. Maksudnya adalah literasi membaca berhubungan dengan kemampuan berpikir peserta didik. Dalam arti tersebut bahwa tidak hanya sekedar mengeja ataupun bahkan bukan sekedar mempunyai keterampilan dalam membaca. Peserta didik yang memiliki kompetensi penalaran dan bisa memecahkan masalah dalam berbagai bidang yang termasuk literal maupun sains. Pada pernyataan ini, bertujuan agar dengan adanya literasi membaca dapat mendorong peserta didik untuk memiliki daya nalar seperti ingatan jangka panjang (Long Term Memory) (Ekaputra, 2020).

Ada beberapa langkah efektif bagi peserta didik untuk meningkatkan kemampuan menalar dengan membaca yang lebih beragam, berkualitas, dan memiliki keterampilan agar bisa dikembangkan potensinya dalam kegiatan literasi membaca. Dengan adanya kegiatan literasi membaca, kehidupan berhubungan banyaknya aspek dalam lingkungan sekitarnya seperti kegiatan berpikir kreatif, kritis, aktif, dan inovatif. Hal ini sejalan dengan era 4.0 mengarahkan kemahiran pada keterampilan. Untuk melatih keterampilan membaca, peserta didik diarahkan untuk menyukai buku mereka yang ingin dibaca. Dengan hal itu, peserta didik akan termotivasi untuk membaca tanpa adanya dorongan dari orang lain, sehingga sedikit demi sedikit peserta didik akan menjadi senang dan proses tersebut menjadi kebiasaan (babbits). Peserta didik yang membaca akan otomatis bertanya apa yang belum mereka pahami, sehingga pendidik maupun orangtua di rumah dapat membekali mereka agar dapat berpikir secara kritis.

\section{Metode untuk Meningkatkan Motivasi Literasi Membaca}

Selain numbered heads together, ada beberapa metode untuk meningkatkan motivasi literasi membaca di antara lain yaitu seperti CIRC (Cooperative Integrated Reading and Composition) (Valencia et al., 2006), SQ3R (Survey, Question, Read, Resite, and Review) (Fahmawati et al., 2017), Latihan Terbimbing (Nasution, 2017), Reciphoral Teaching (Andira et al., 2018), SAVI (Somatik, Auditori, Visual, Cerdas) (Azizah \& Sujana, 2016), Numbered Heads Together adalah model yang dikembangkan oleh (Ulya, 2017) yang memungkinkan kalangan pelajar untuk berpartisipasi dalam memperoleh pengetahuan yang tercakup pada kursus atau memeriksa proses belajarnya mengenai konten pembelajaran.

Menurut (Wardani \& Siswanto, 2016) kelebihan dari numbered heads together bagi pendidik adalah agar lebih mudah dalam memberikan materi bahasa Indonesia sehingga peserta didik juga mudah dalam menerima dan memahami materi dari proses pembelajaran. Keuntungan dari model numbered heads together yaitu bagi peserta didik tentunya siap, bisa berdiskusi dengan serius, peserta didik dapat saling mengajari kepada teman yang tidak bisa, dan dapat menumbuhkan sikap sosial pada setiap siswa.

\section{Definisi dan Sintak Numbered Heads Together}

Secara umum penomoran bersama adalah semacam pemahaman, menekankan bahwa siswa mencari dalam kegiatan, dan kemudian menanganinya, dan kemudian tahap selanjutnya adalah 
melaporkan informasi dari berbagai bahan referensi, dan akhirnya mempresentasikannya ke seluruh kelas secara bersama-sama (Huninhatu et al., 2021).

Numbered Heads Together, secara khususnya yakni berbagai diskusi dari masing-masing kelompok. Menurut (Siswa et al., 2019), Cooperative Learning model yang dikembangkan oleh Russ Frank cocok untuk memastikan tanggung jawab individu dalam belajar. Adapun manfaat lainnya untuk meningkatkan kerjasama peserta didik, numbered heads together dapat dilaksanakan pada semua bidang mata pelajaran terutama dalam pelajaran bahasa Indonesia dalam tingkatan kelas.

Sintak dan tahapan penerapan numbered heads together pada pengertiannya hampir sama setiap peneliti, perbedaannya mungkin hanya dalam pengembangannya saja namun inti pembelajaran dalam sintaknya sama.

Pertama, setiap peserta didik dibagi ke dalam kelompok. Kedua, pada kelompok diberikan nomor kepala yang sudah ditentukan pada setiap peserta didik. Ketiga, pendidik memberikan beberapa pertanyaan pada masing-masing setiap kelompok untuk melakukan tugasnya. Keempat, setiap kelompok kepala akan memulainya dengan cara berdiskusi agar dapat memastikan jawaban yang paling tepat. Kelima, pendidik memanggil dari setiap anggota kepala secara acak, tahapan terakhir yaitu dengan nomor kepala yang akan dipanggil oleh pendidik kemudian akan didemonstrasikan jawaban yang disampaikan dari hasil diskusi kelompoknya.

\section{Pengaruh Numbered Heads Together Terhadap Motivasi Literasi}

Numbered Heads Together akan terdapat pengaruh pada motivasi peserta didik dalam aktivitas setiap literasi. Hal ini karena numbered heads together mengedepankan aturan khusus yang disusun sebagaimana agar dapat mempengaruhi pola interaksi, meningkatkan kompetensi akademik dalam kegiatan literasi.

Penelitian sebelumnya terkait pembelajaran kooperatif kepala bilangan berbasis metode saintifik untuk mempelajari motivasi hasil belajar siswa kelas IV SDN 04 Nanga Pinoh mendeskripsikan bahwa terdapat pengaruh terhadap hasil belajar (berdasarkan t hitung dan $\mathrm{t}$ tabel yang diberikan berdasarkan metode ilmiah Sebelum dan sesudah model numbering head together Dari penelitian ini diketahui bahwa numbering head together efektif untuk meningkatkan hasil belajar (Corebima et al., 2016).

Penelitian terdahulu yang dilakukan oleh (Maman dan Rajab 2016) bahwa meningkatkan hasil belajar menerapkan numbered heads together, dari awal siklus I, 44\% tergolong sangat baik, 56\% sangat baik, dan tidak ada siswa yang memiliki nilai rendah. Pada siklus II, 84\% siswa dinilai sangat baik, 16\% siswa dinilai sangat baik, dan tidak ada siswa yang mendapat nilai rendah, dan tidak ada siswa yang tergolong kurang.

Hasil penelitian yang dilaksanakan oleh (Putra et al., 2019) menjelaskan bahwa numbered heads together sangat berpengaruh terhadap motivasi dan hasil belajar dibandingkan dengan strategi pembelajaran ARIAS (Assurance Relevance Interest Assessment Satisfaction). Diharapkan peneliti menggunakan numbered heads together karena hal ini terbukti efektif dalam meningkatkan motivasi belajar dan hasil belajar.

Dari analisis jurnal tersebut, dapat disimpulkan bahwa model numbered heads together akan memberikan pengaruh terhadap hasil belajar, dan ini ditemukan pada semua jenjang mulai dari tingkat Sekolah Dasar, Sekolah Menengah Pertama, dan Sekolah Menengah Atas.

Penerapan numbered heads together pada tahun 2016 lebih cenderung banyak diterapkan pada tingkat sekolah dasar. Menurut Yusnarti, usia sekolah dasar teknik belajarnya masih diselingi dengan teknik bermain agar peserta didik adanya motivasi dalam belajar. Dengan diberikan nomor di kepala masing-masing tiap kelompok, peserta didik merasa terangsang untuk mengikuti kegiatan dari awal sampai akhir pembelajaran dengan penuh semangat. Oleh karena itu, persepsi 
terhadap penerapannya memiliki pengaruh yang sangat signifikan terhadap motivasi dan hasil belajar. Menurut (Purnomo \& Arafatun, 2020), mengatakan bahwa numbered heads together dapat menjadi lebih baik. (Slavin, 2005) berkata, berdiskusi secara berkelompok akan memberikan pengaruh sikap sosial terhadap setiap peserta didik.

\section{Pengaruh Numbered Heads Together Terhadap Kemampuan Literasi}

Penggunaan Numbered Heads Together terhadap kemampuan literasi akan memberikan pengaruh setiap peserta didik dalam proses kemampuan literasinya. Model numbered heads together dilatarbelakangi oleh aliran filsafat konstruktivisme yang dikemukakan oleh (Dian et al., 2021) menjelaskan pembelajaran konstruktivisme merupakan sebuah proses aktif, tentang membantu peserta didik mengkonstruksi makna sendiri bukan tentang jawaban benar tanpa jawaban yang benar-benar memahami konsepnya.

Mengingat inovatifnya kemampuan literasi maka terdapat beberapa penelitian terdahulu mengenai keberhasilan menggunakan atau menerapkan numbered heads together ini seperti penelitian (Arka, 2020) yang menegaskan bahwa pembelajaran kooperatif numbered heads together akan memberikan kontribusi lebih baik terhadap kemampuan literasi.

Berdasarkan pemaparan di atas pembelajaran kooperatif numbered heads together sudah teruji lebih efektif dibandingkan dengan pembelajaran secara yang biasa. Selain itu (Arrosyad \& Nugroho, 2020) menjelaskan bahwa pendidik lebih mudah menjelaskan atau menyampaikan materi secara lebih jelas dengan menerapkan numbered heads together daripada penjelasan pendidik secara lisan seperti menggunakan ceramah.

(Yanti \& Sriyati, 2017) mengatakan bahwa numbered heads together dapat menjadikan setiap peserta didik menjadi lebih aktif, sehingga kemampuan literasi menjadi terasah karena peserta didik dituntut untuk mengungkapkannya melalui tahapan questioning, head together, and answering.

\section{PEMBAHASAN}

\section{Numbered Heads Together dan Motivasi Belajar}

Pada pembahasan ini, peneliti akan membahas kenapa pembelajaran kooperatif Numbered Heads Together dapat meningkatkan motivasi belajar? Faktor apa saja ? Apakah ada kaitannya dengan satuan pendidikan?

Pembelajaran kooperatif Numbered Heads Together dapat meningkatkan motivasi belajar setiap peserta didik (Ulya, 2017). Hal ini terbukti pada setiap penelitian yang menggunakan uji coba pembelajaran biasa dengan pembelajaran numbered heads together akan memberikan perbandingan serta memberikan pengaruh pada motivasi belajar peserta didik baik dalam segi pembelajaran. Pembelajaran numbered heads together dapat memberi setiap kesempatan peserta didik untuk saling berbagi ide-ide dan dapat mempertimbangkan jawaban yang tepat (Fazrul Sandi Purnomo, 2019). Metode ini juga dapat mendorong peserta didik dalam motivasi semangat kerjasama antar peserta didik dengan lainnya terhadap permasalahan mereka hadapi dalam kegiatan proses pembelajaran. Peserta didik diharapkan antusias dalam memahami permasalahan dan jawaban karena semua akan berpusat terhadap mereka atau student center learning (SCL) karena pada numbered heads together pendidik akan menunjuk peserta didik yang mewakili kelompok tanpa memberitahu terlebih dahulu siapa yang akan mewakili. Karena selain dari pada itu, dengan kegiatan numbered beads together pembelajaran tidak akan membuat bosan terhadap materi pelajaran sehingga peserta didik terus termotivasi untuk belajar.

Keberhasilan peserta didik dipengaruhi oleh berbagai faktor dalam proses pembelajaran, yaitu dari faktor internal dan eksternal (Supriyanto \& Iswandiri, 2017). Salah satu faktor internal 
adalah motivasi belajar. Dalam kegiatan belajar diperlukan motivasi, karena ketika siswa tidak termotivasi untuk belajar maka tidak ada proses belajar di dalam kelas.

Menurut Undang-Undang Nomor 20 tahun 2003 Sistem Pendidikan Nasional menjelaskan bahwa satuan pendidikan adalah kelompok layanan pendidikan yang menyelenggarakan pendidikan pada berbagai jenjang dan jenis pendidikan melalui jalur formal, non formal, dan informal. Melihat dari pengertian di atas, satuan pendidikan merupakan kinerja pendidik pada kegiatan belajar yang sudah dirancang sesuai tujuan yang diharapkan. Hal ini berarti ada hubungan satuan pendidikan dengan motivasi belajar, dimana semakin tinggi motivasi belajar peserta didik dengan kinerja pendidik dalam kegiatan proses pembelajaran maka akan tinggi pula hasil belajar setiap peserta didik. Begitu sebaliknya, jika motivasi peserta didik menurun maka rendah pula hasil belajar sehingga kinerja pendidik tidak tercapai.

Terbentuknya motivasi belajar disebabkan oleh faktor internal yaitu keinginan untuk berhasil dan kebutuhan untuk mendorong belajar. Faktor eksternal dianggap paling kondusif untuk menciptakan lingkungan belajar yang kondusif dan kegiatan belajar yang menarik, sehingga merangsang motivasi belajar siswa. Kedua faktor tersebut disebabkan oleh adanya rangsangan tertentu yang memungkinkan siswa berpartisipasi aktif dalam kegiatan pembelajaran dan proaktif dalam proses pembelajaran. Sebagaimana dijelaskan oleh (Kuncahyono, 2017), kegiatan proses belajar dan motivasi belajar dianggap sebagai kekuatan pendorong keseluruhan untuk menghasilkan kegiatan belajar, memberikan arahan untuk kegiatan belajar, dan mencapai tujuan belajar yang diharapkan.

Menurut (Khoirurrosyidin, 2015), bahwa motivasi mempunyai tiga komponen utama, yaitu a) kebutuhan, yang terjadi ketika individu merasakan ketidakseimbangan antara peserta didik miliki dan apa yang mereka harapkan (b) dorongan, Merupakan semacam kekuatan spiritual. berorientasi untuk mencapai harapan atau tujuan Inilah inti dari motivasi (c) tujuan, yaitu tujuan yang ingin dicapai. Tujuan ini akan membimbing setiap siswa. Tugas pendidik adalah mempelajari motivasi, terutama untuk memperdalam motivasi diri. Motivasi belajar dapat dikaitkan dengan semacam dorongan dari luar dan dari dalam diri untuk mengikuti harapan pendidik sekolah dalam proses pembelajaran.

\section{Numbered Heads Together dan Kemampuan Literasi}

Berbagai program dikembangkan pemerintah untuk meningkatkan kemampuan literasi membaca salah satunya menentukan metode yang cocok pada kegiatan proses pembelajaran. Meningkatnya literasi membaca akan menjadi harapan menuju lahirnya generasi masa depan yang unggul, andal, dan berbudi pekerti luhur sebagai modal untuk menghadapi permasalahan abad 21.

Penggunaan Numbered Heads Together akan memberikan pengaruh pada kemampuan literasi membaca terutama pada pelajaran bahasa Indonesia. Dengan kegiatan literasi, peserta didik mampu melakukan pembiasaan mereka dengan melakukan tahapan sintak dari pembelajaran numbered heads together. Hal ini ada kaitannya dengan satuan pendidikan, dimana kurikulum mencanangkan yang namanya KKM (Kriteria Ketuntasan Minimal) sehingga peserta didik dituntut untuk mencapai KKM yang telah ditentukan pihak sekolah tertentu. Dengan kegiatan numbered heads together terbukti bahwa akan memberikan pengaruh terhadap peserta didik. Karena dari tujuan yaitu peningkatan aktivitas pada saat mengerjakan evaluasi yang disajikan pendidik sehingga bisa terpengaruh terhadap hasil ketuntasan belajarnya. 


\section{Bagaimana Numbered Heads Together Dapat Memotivasi dan Memenuhi Kriteria Kemampuan Minimum Literasi Membaca?}

Adapun tahapan pendidik dalam kegiatan literasi membaca menggunakan numbered heads together agar peserta didik dapat berpengaruh pada motivasi dan kemampuan minimumnya sebagai berikut.

a) Pertama, informasi akan disampaikan pendidik adalah langkah-langkah yang ditetapkan dengan rencana pelaksanaan sesuai kurikulum.

b) Kedua, pendidik membagi beberapa kelompok yang disesuaikan dengan jumlah peserta didik yang hadir dalam kelas.

c) Ketiga, guru menyiapkan nomor kepala yang terbuat dari karton ukuran $5 \times 5 \mathrm{~cm}$. Pemberian nomor agar memudahkan pendidik untuk melakukan pengecekan pada kegiatan literasi membaca terhadap pemahaman membaca peserta didik.

d) Keempat, setelah kelompok dibentuk pendidik kemudian membagikan nomor 1 sampai dengan jumlah $\mathrm{n}$ ( $\mathrm{n}$ adalah jumlah peserta didik yang ada pada kelompok) artinya dalam kelompok sudah memiliki nomor yang berbeda.

e) Kelima, pendidik meminta untuk memahami isi teks bacaan pada kegiatan literasi membaca maka sebelumnya pendidik menyiapkan beberapa teks bacaan agar setiap anggota kelompok dapat memahami isi teks bacaan kegiatan literasi membaca secara bersama-sama.

f) Keenam, pendidik memberikan pertanyaan setiap kepala dan harus dikerjakan setiap kelompok.

g) Ketujuh, pendidik meminta untuk berdiskusi agar mampu menganalisis dan meyakinkan bahwa setiap kelompok dapat memahami isi teks bacaan kemudian menjawab pertanyaan yang disajikan.

h) Kedelapan , setelah semua percaya atas jawaban selanjutnya pendidik memanggil nomor secara acak, dan kemudian meminta untuk menggunakan nomor yang sama.Inilah yang disebutkan guru saat menjawab pertanyaan. Ada kala dengan nomor tidak dapat menjawab pertanyaan akan diberikan pada anggota kelompok yang lain.

i) Kesembilan, peserta didik dengan pendidik menyimpulkan secara bersama terkait materi yang sudah dipelajari.

j) Kesepuluh, kegiatan literasi yaitu kegiatan evaluasi, dimana pada kegiatan akhir adalah apakah terdapat pengaruh terhadap motivasi dan kemampuan minimum pada kegiatan literasi membaca.

Berdasarkan kegiatan tersebut dilaksanakan dalam proses di kelas maka akan memberikan dampak motivasi literasi. Pada dasarnya tugas pendidik didasarkan pada upaya membimbing peserta didik dalam bidang ilmunya. Pendidik menghubungi siswa sebanyak mungkin, bersimpati dengan karakter dan masalahnya, dan merespons dengan berbagai cara, membantu siswa menggambarkan masalah dan perasaannya, bertanggung jawab atas perlakuannya, dan merencanakan tujuan dan metode, model, metode, dan strategi. karakteristik peserta didik untuk mencapai kemampuan dasar, indikator pencapaian dan tujuan yang diharapkan oleh pendidik, salah satunya dengan menggunakan nomor kepala.

\section{SIMPULAN}

Simpulan dari hasil artikel review, peneliti menyimpulkan bahwa dengan perlakuan (treatment) mengenai penggunaan model pembelajaran numbered heads together berupa pertanyaan dan jawaban 
bisa mempermudah peserta didik dalam kegiatan literasi terhadap motivasi dan kemampuan minimumnya terutama pada pelajaran bahasa Indonesia, dapat berinteraksi dengan peserta didik satu maupun yang lainnya. Peserta didik akan lebih memahami isi teks bacaan pada kegiatan literasi membaca sesuai dengan materi yang dipelajarinya agar lebih aktif serta dapat memecahkan permasalahan yang yang dihadapi.

Dengan adanya pemberian treatment peserta didik termotivasi dan sangat antusias pada aktivitas pembelajaran. Maka dari itu, dapat dikatakan bahwa kegiatan literasi membaca bahasa Indonesia berupa pertanyaan dan jawaban yang diberikan setiap kelompok akan memberikan pengaruh dalam kegiatan proses dan hasil pembelajaran.

\section{REFERENSI}

Andira, T., Santoso, B., \& Yusup, M. (2018). Penerapan model pembelajaran reciprocal teaching ditinjau dari kemampuan penalaran matematis peserta didik pada materi bangun datar segiempat Applying of reciprocal teaching learning model viewed from students ' mathematical reasoning on quadrilateral mat. Pythagoras, 13(1), 88-98.

Arifian, F. D. (2018). SKETSA KONSEP LITERASI MODERN. 30 Jurnal Pendidikan Dan Kebudayaan Missio, 10(10), 27-38.

Arka, I. W. (2020). Pengembangan Model Pembelajaran Inovatif Berbasis Kompetensi. Widyacarya: Jurnal Pendidikan, Agama Dan http://jurnal.stahnmpukuturan.ac.id/index.php/widyacarya/article/view/792

Arrosyad, M. I., \& Nugroho, F. (2020). Development of Variations in Greetings Before and After Learning the Moral Character of Students in Elementary Schools. Dinamika Jurnal Ilmiah Pendidikan Dasar, 12(2), 89. https://doi.org/10.30595/dinamika.v12i2.8233

Azizah, N., \& Sujana, A. (2016). Penerapan Pendekatan Somatis Auditori Visual Intelektual Belajar Siswa. Jurnal Pena Ilmiah, 1(1), 491-500.

Busroli, A. (2019). Pendidikan akhlak Ibnu Miskawaih dan Imam al-Ghazali dan relevansinya dengan pendidikan karakter di Indonesia. Atthulab: Islamic Religion Teaching and Learning Journal, 4(2), 236-251. https://doi.org/10.15575/ath.v4i2.5583

Corebima, A. D., Susilo, H., \& Nursyamsi. (2016). Pengaruh Strategi Pembelajaran Numbered Heads Together ( Nht) Terhadap Keterampilan Berpikir Kritis Siswa Sma. Jurnal Pendidikan: Teori, Penelitian Dan Pengembangan, 1(10), 1993-1998.

Dian, R., Putri, P., \& Siregar, V. V. (2021). Implementasi Pembelajaran Tematik di Sekolah Dasar Pada Masa Pandemi Covid-19 Ditinjau Dari Teori Konstruktivisme. Journal of Integrated Elementary Education, 1(1), 1-15.

Ekaputra, F. (2020). Efektivitas Laboratorium Virtual Kimia Berbasis Hypertext Markup Language 5 Untuk Meningkatkan Sikap Ilmiah Dan Prestasi Belajar. Tarbawy: Jurnal Pendidikan Islam, 7(1), 6-16. https://doi.org/10.32923/tarbawy.v7i1.1201

Fahmawati, F., Rusdi, R., \& Komala, R. (2017). Pengaruh Model Pembelajaran Survey, Question, Read, Recite, Review (SQ3R) dan Kemampuan Berpikir Kritis terhadap Hasil Belajar Peserta Didik SMA. Jurnal Pendidikan Biologi, 10(2), 55-62. https://jurnal.uns.ac.id/bioedukasi/article/view/17606 
Fazrul Sandi Purnomo, S. K. A. (2019). Penerapan Pola Pembelajaran Di SD IT Al Bina Pangkalpinang. Penerapan Pembelajaran Menggunakan Media Pembelajaran Berbasis Animasi Flash Pada Mata Pelajaran Menggunakan Listrik Di SMKN 5 Padang, 7(1), 42-46.

Handayani, F. (2020). Building Students' Critical Thinking Skills through STEM-Based Digital Literacy during the Pandemic Period Covid 19. Cendekiawan, 2(2), 69-74. https://doi.org/https://doi.org/10.35438/cendekiawan.v2i2.184

Handayani, F. (2020).Membangun Keterampilan Berpikir Kritis Siswa Melalui Literasi Digital Berbasis STEM Pada Masa Pandemik Covid-19. Jurnal Cendekiawan, 2(2), 83-87. Diambil dari https://doi.org/10.35438/cendekiawan.v2i2.184

Huninhatu, A. F., Pudjiastuti, S. R., \& Sutisna, M. (2021). Pengembangan Model Numbered Heads Together Secara Daring dalam Meningkatkan Pemahaman Nilai Pancasila dan Pembentukan Karakter Disiplin. Jurnal Citizenship Virtues, 1(1), 35-41. https://doi.org/10.37640/jcv.v1i1.914

Ilmasari, F., \& Alhadi, S. (2019). Peran Kepala Sekolah Dalam Mengembangkan Kultur Sekolah Di Sd Muhammadiyah Sangonan 2. Jurnal Fundadikdas (Fundamental Pendidikan Dasar), 2(1), 19. https://doi.org/10.12928/fundadikdas.v2i1.677

Khoirurrosyidin. (2015). Pendidikan Karakter Melalui Pemahaman Media Literacy. Jurnal Aristo, 3(1), 49-61.

Kuncahyono, K. (2017). Analisis Penerapan Media Berbasis Komputer Pada Pembelajaran Tematik Terpadu Di Sekolah Dasar. Jurnal Pemikiran Dan Pengembangan Sekolah Dasar (JP2SD), 5(2), 773. https://doi.org/10.22219/jp2sd.vol5.no2.773-780

Leu, B. (2020). Pembelajaran Tahsin Tilawah Al-Quran Untuk Pembaca Pemula. Ilmuna, 2(2), 134 154. https://jurnal.stituwjombang.ac.id/index.php/ilmuna/article/view/159

Maman, M, \& Rajab Aryani, A. (2016). The Implementation of Cooperative Learning Model Number Heads Together (NHT) in Improving the Student's Ability in Reading Comprehension . International Journal of Evaluation and Research in Education (IJERE) , 5(2), 174180. Diambil dari : http://iaesjournal.com/online/index.php/IJERE

Muntari, L. (2016). Pengembangan bahan ajar membaca Bahasa Indonesia untuk kelas V SD dengan Model Dick dan Carey. Media Didaktika, 2(2), 175-182.

Nasution, M. K. (2017). Penggunaan Metode Pembelajaran Dalam Peningkatan Hasil Belajar Siswa. Jurna Ilmiah Bidang Pendidikan, 11(1), 9-16.

Purnomo, F. S., \& Arafatun, S. K. (2020). Penerapan Pola Pembelajaran Di SD IT Al Bina Pangkalpinang. Tarbawy: Jurnal Pendidikan Islam, 7(1), 42-46. https://doi.org/10.32923/tarbawy.v7i1.1180

Putra, A., Tobing, H., Rahajeng, O., \& Yuhan, R. (2019). The Indonesian Journal of Social Studies. The Indonesian Journal of Social Studies, 2(2), 37-45. https://journal.unesa.ac.id/index.php/jpips/article/view/8508/4156

Rahim, F. (2008). Pengajaran Membaca Di Sekolah Dasar. Jakarta: Bumi Aksara.

Rifqi, H. (2016). Analisis Semiotika Logo Bank Nagari Bank Pembangunan Daerah Sumatera Barat. Journal of Chemical Information and Modeling, 53(9), 1689-1699. 
Rofiah, A. (2019). Implementasi Program Pendidikan Karakter Dan Program Gerakan Literasi Sekolah Dalam Membentuk Sikap Kemandirian Belajar Siswa Di Sdn Percobaan 2 Dan Sd Muhammadiyah Sapen. G-Couns: Jurnal Bimbingan Dan Konseling, 3(2), 172-180. https://doi.org/10.31316/g.couns.v3i2.310

Ruhaena, L. (2015). Model Multisensori: Solusi Stimulasi Literasi Anak Prasekolah. Jurnal Psikologi, 42(1), 47. https://doi.org/10.22146/jpsi.6942

Siswa, P. K., Siswa, P. K., \& Pendidikan, G. P. (2019). Pembelajaran Inovatif dalam Pembentukan Karakter Siswa. Mimbar Pendidikan, 4(1), 21-34. https://doi.org/10.17509/mimbardik.v4i1.16968

Supriyanto, W., \& Iswandiri, R. (2017). Kecendurungan Sivitas Akademika Dalam Memilih Sumber Referensi. Berkala Ilmu Perpustakaan Dan Informasi, 13(1), 79-86.

Suspahariati, \& Susilawati, R. (2020). Penerapan Sistem WFH (Work From Home) dan Dampaknya terhadap Kinerja Staf dan Dosen Unipdu Jombang selama Pandemi Covid-19 Pendahuluan Perubahan-perubahan dari tahun ke tahun kerap dirasakan masyarakat dengan berbagai faktor penyebab . Pada awal 2020 ,. Jurnal Manajemen Dan Pendidikan Islam, 6(2), 229-240.

Slavin, R. E. (2005). Cooperative Learning (Theory, Research, and Practice). Bandung: Nusa Media.

Ulya, N. M. (2017). Pengaruh Metode Pembelajaran dan Tipe Kepribadian Terhadap Hasil Belajar Bahasa Arab (Studi Eksperimen Pada MAN 1 Semarang). Nadwa Jurnal Pendidikan Islam, 10(1), 1. https://doi.org/10.21580/nw.2016.10.1.867

Undang-Undang Republik Indonesia Nomor 12 tentang Pendidikan Tinggi. (2012). Jakarta: Kemdikbud.

Valencia, S. W., Place, N. A., Martin, S. D., \& Grossman, P. L. (2006). Curriculum materials for elementary reading: Shackles and scaffolds for four beginning teachers. Elementary School Journal, 107(1), 93-120. https://doi.org/10.1086/509528

Wardani, C. K., \& Siswanto, S. (2016). Implementasi Model Pembelajaran Kooperatif Numbered Heads Together (Nht) Untuk Meningkatkan Prestasi Belajar. Jurnal Pendidikan Akuntansi Indonesia, 13(2), 89-96. https://doi.org/10.21831/jpai.v13i2.10312

Yanti, W. A., \& Sriyati, S. (2017). Pengaruh Model Pembelajaran Kooperatif Tipe Numbered Heads Together (Nht) Terhadap Kemampuan Siswa Mengajukan Pertanyaan Pada Tema Pemanasan Global. Edusains, 9(1), 24-33. https://doi.org/10.15408/es.v9i1.1982

Zonalisa Fhatri. (2019). Perspektif Orangtua Terhadap Anak Autisme dan Peranannya Dalam Terapi ( Studi Kasus PLA Provinsi Kepulauan Bangka Belitung ). Al-Mudarris: Jurnal Ilmiah Pendidikan Islam, 2(2), 154-169. 